\title{
ONENOTE: BINDER DIGITAL CATATAN SISWA
}

Eric Kunto Aribowo, S.S., M.A.

1. Kunjungi laman https://portal.office.com lalu masukkan akun dan kata sandi.

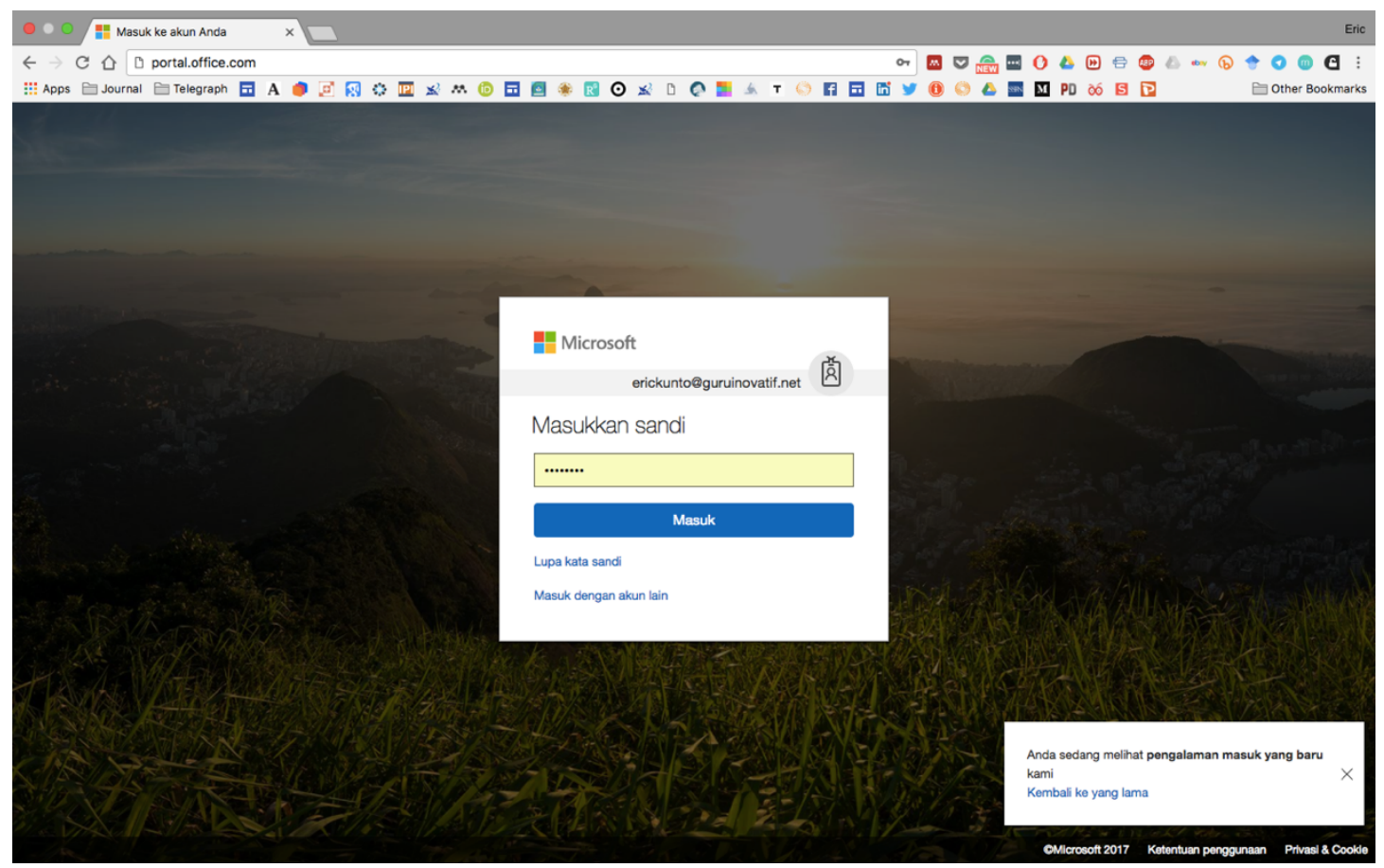

2. Pilih aplikasi OneNote dengan logo N.

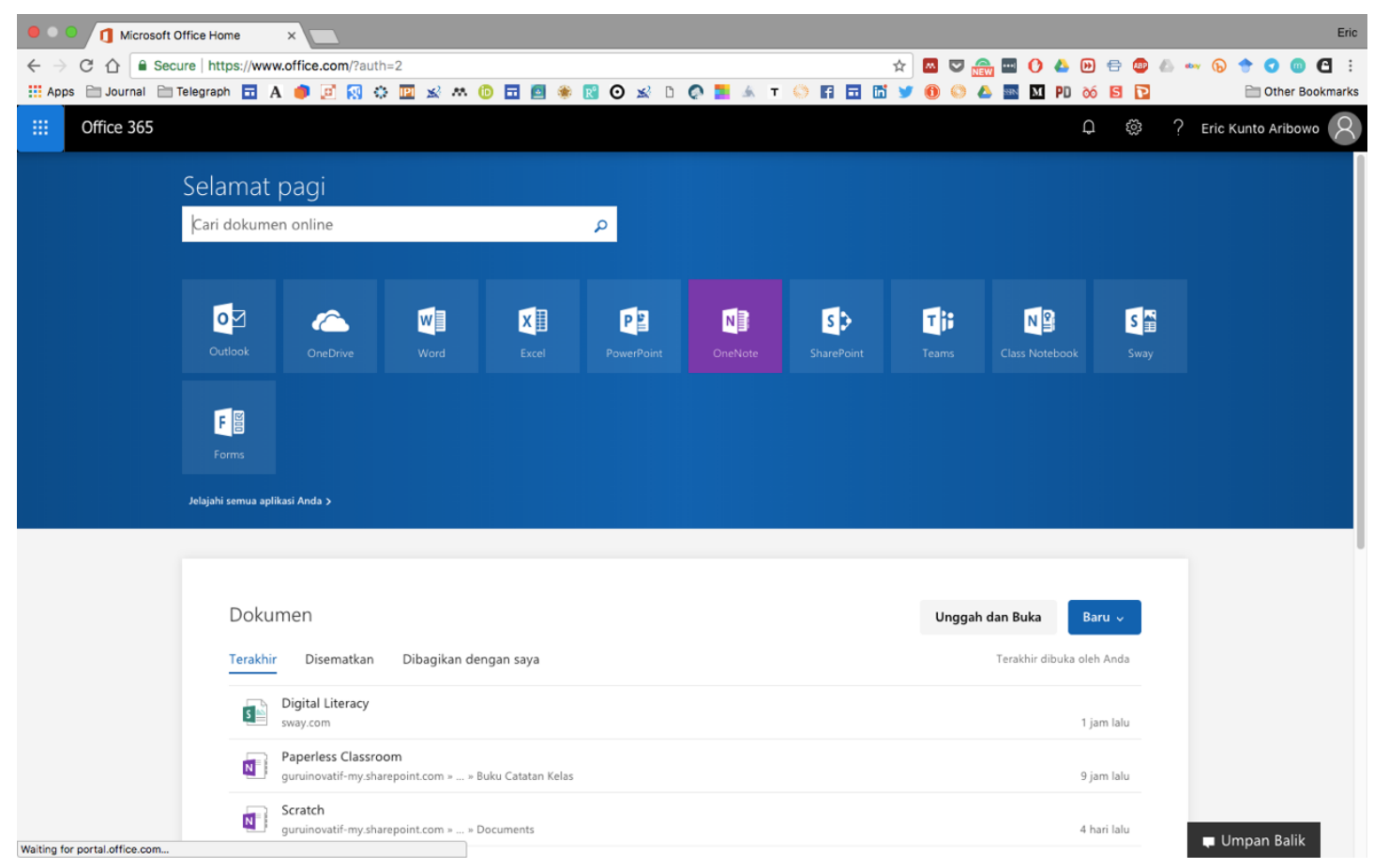


3. "Section" dapat diibaratkan sebuah map untuk mengklasifikasi dalam manajemen catatan dan "Page" sebagai lembaran catatan. Untuk mempermudah, Anda dapat memberikan warna pada "Section" sehingga dapat lebih mudah ditemukan.

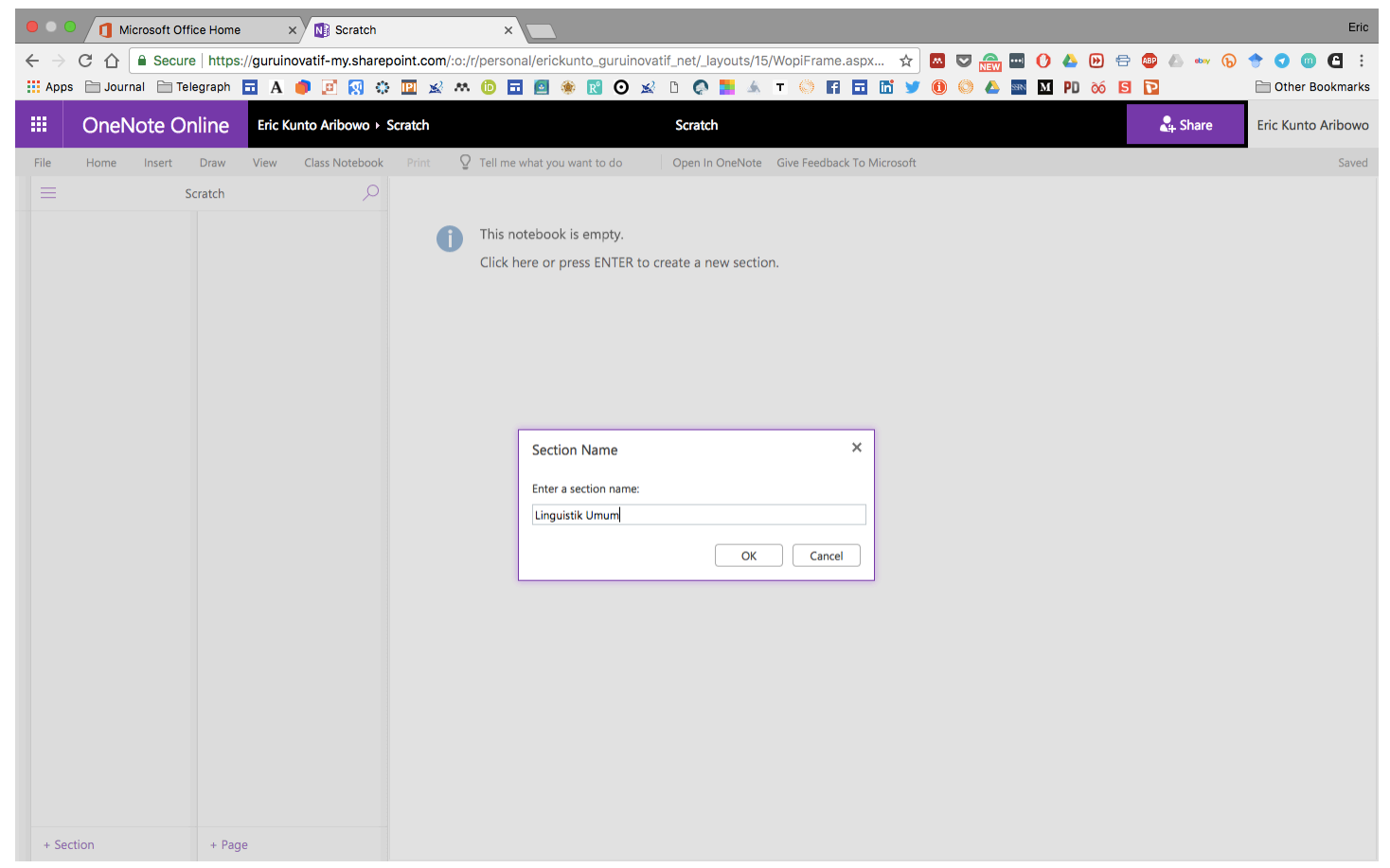


4. Buatlah beberapa "Section" dan "Page" baru yang terkait dengan mata kuliah/mata pelajaran Anda!

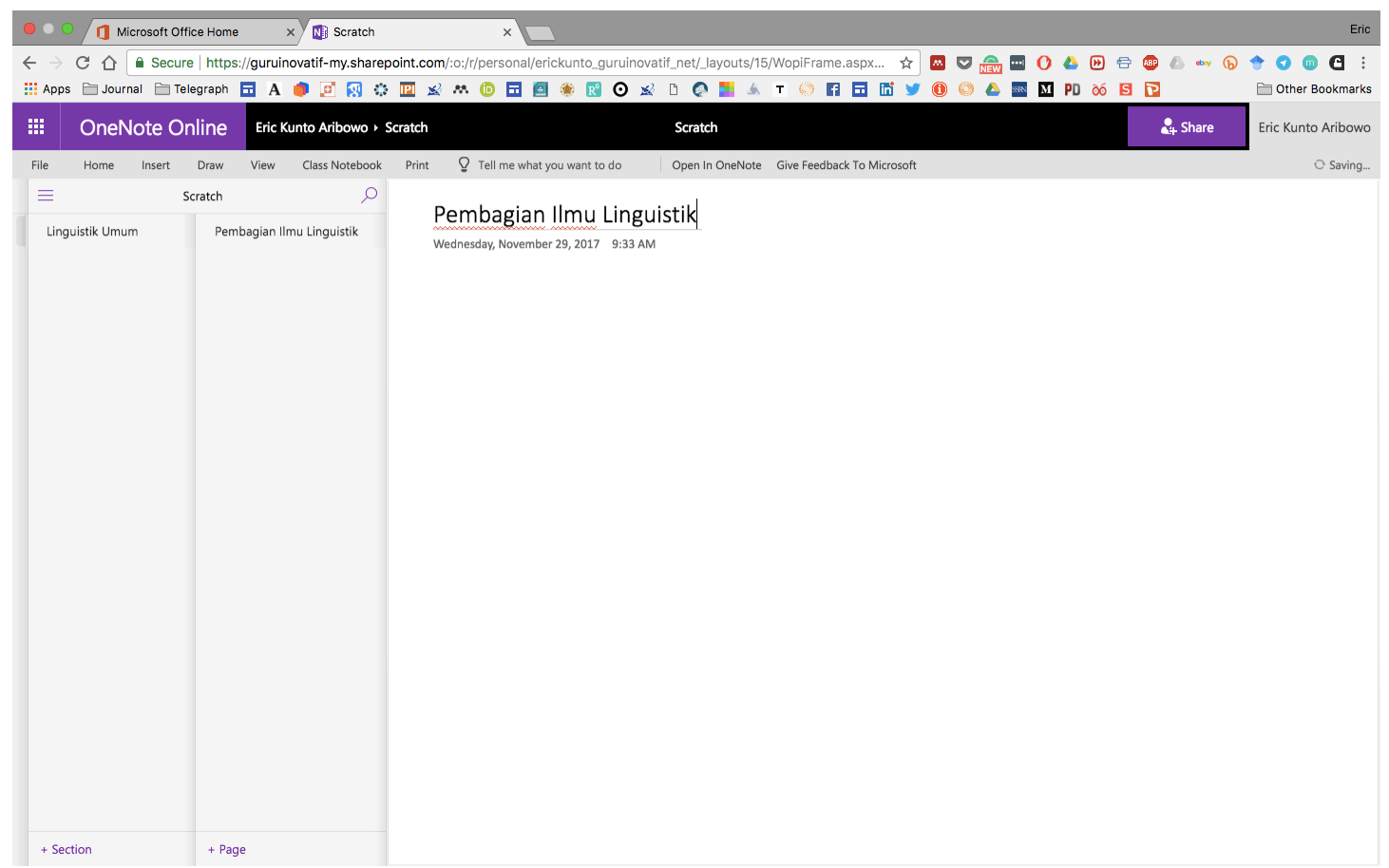

5. Beberapa menu dasar yang terdapat pada OneNote antara lain: "File", "Home", "Insert", "Draw", "View", "ClassNotebook", dan "Print". Menu "File" dapat digunakan apabila Anda ingin membagikan atau mencetak catatan.

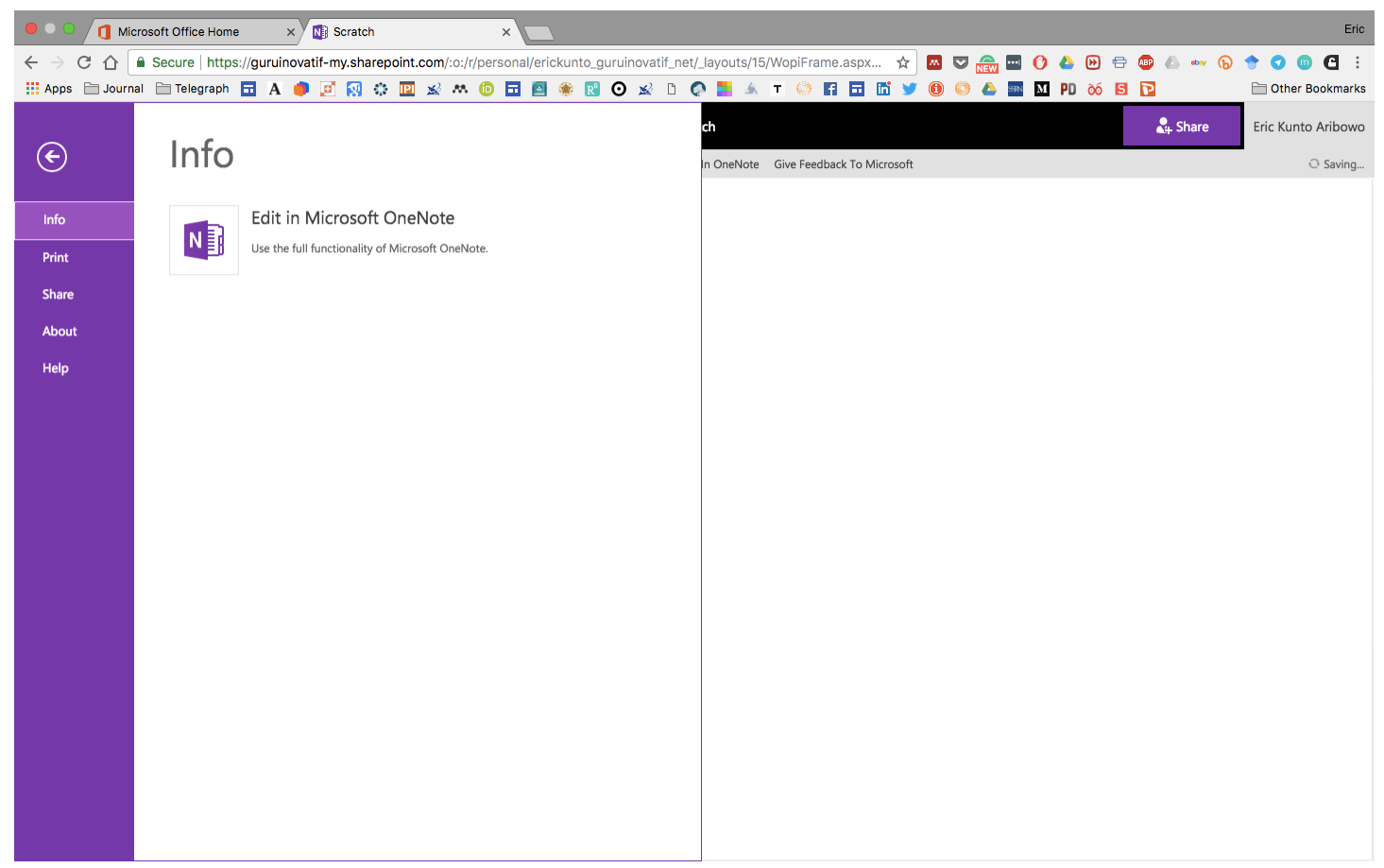


6. Menu "Home" layaknya menu yang terdapat pada Microsoft Office (Word, Excel, dan PowerPoint). Menu ini digunakan untuk mengubah jenis dan ukuran font, mengubah gaya penulisan (bold, italic, underline), memberikan highlight (stabilo warna pada kata-kata penting), serta menambahkan bullet and numbering.

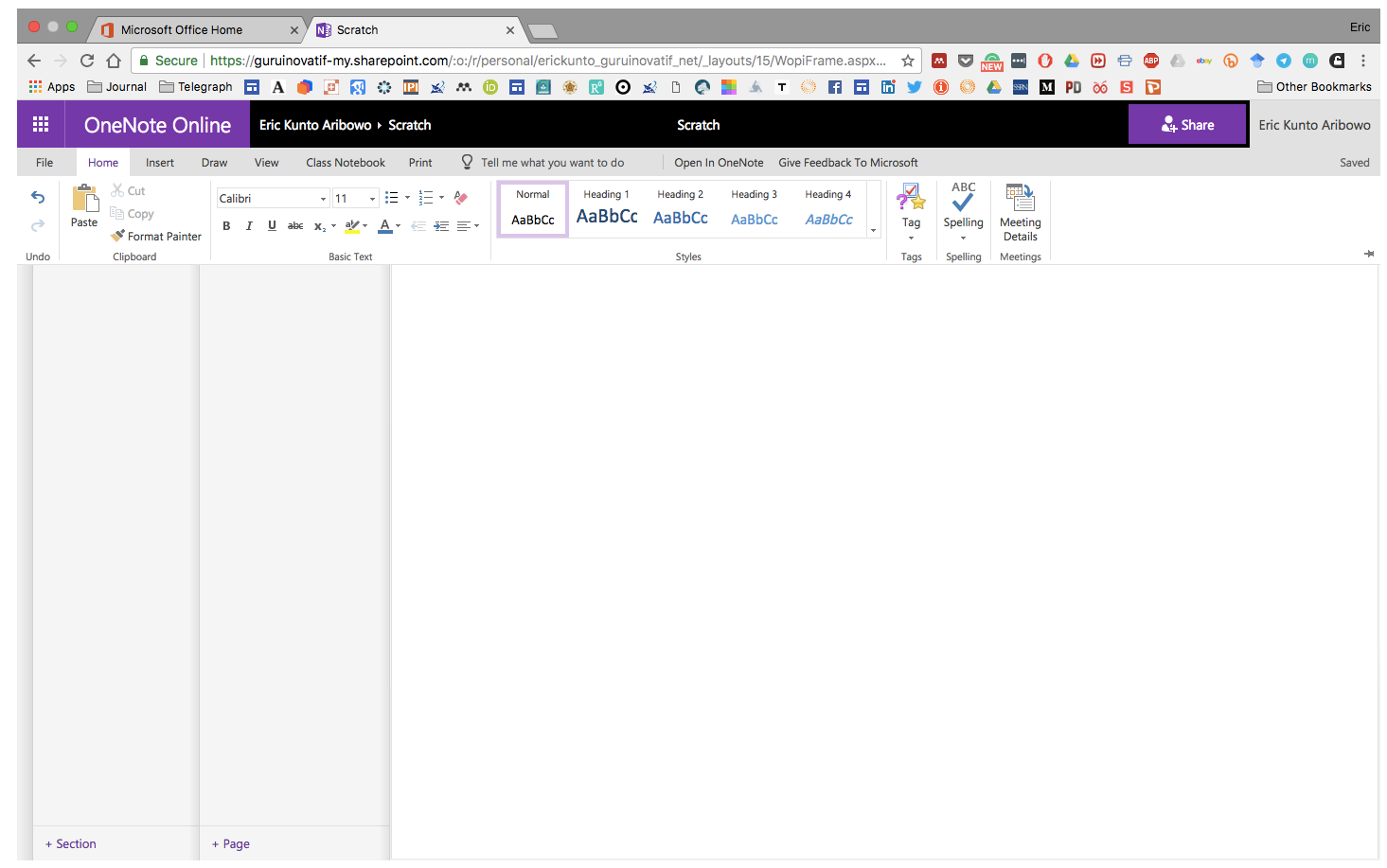

7. Menu "Insert" digunakan apabila Anda ingin menambahkan "Section", "Page", gambar, file, tautan, rekaman suara, simbol, formulir yang dibuat dengan Form, serta stiker.

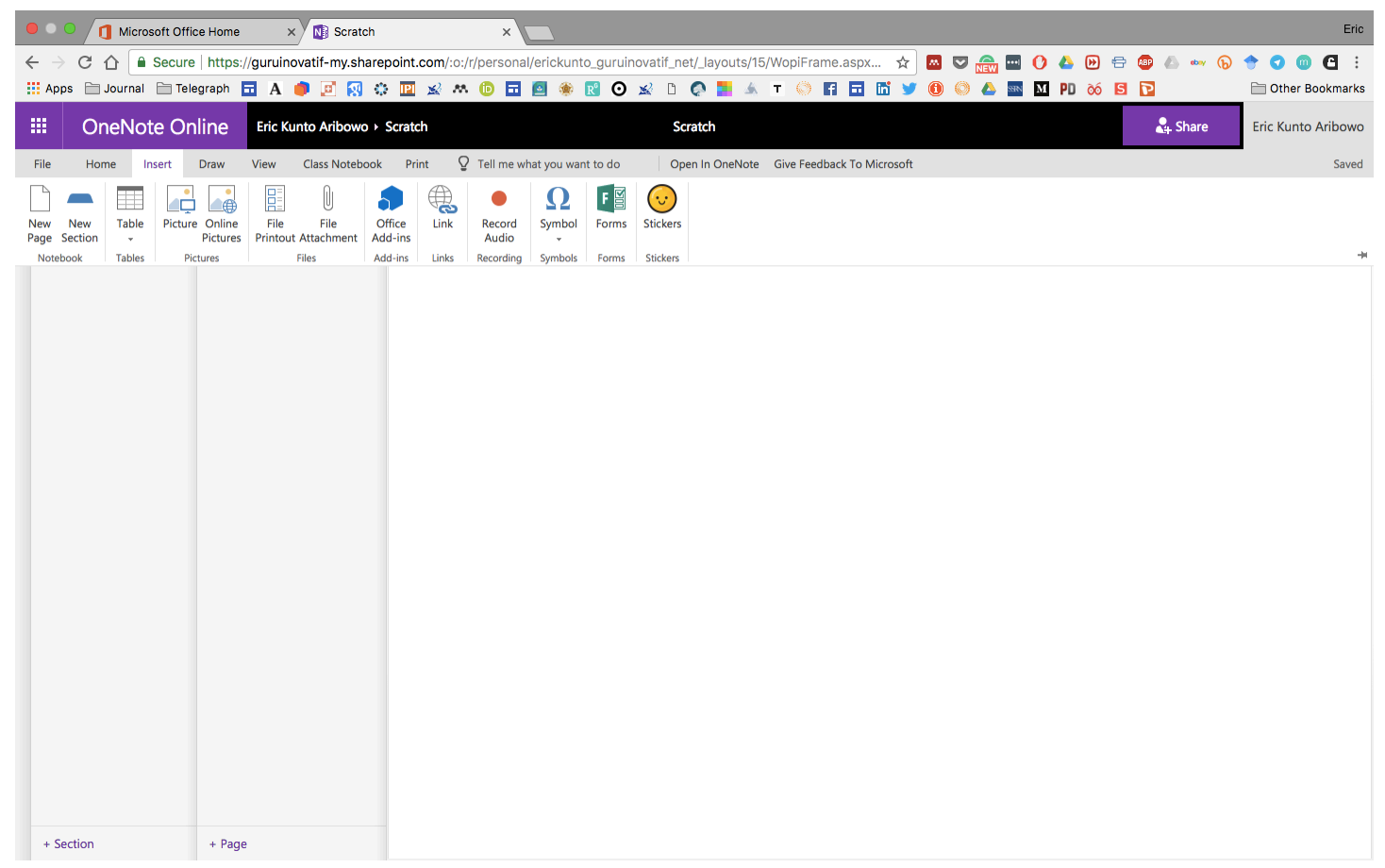


8. Menu "Draw" dapat dimanfaatkan untuk menggambar atau menuliskan dengan menggunakan perangkat mouse. Namun, apabila Anda menggunakan perangkat yang touchscreen, Anda dapat leluasa menggambar menggunakan sylus.

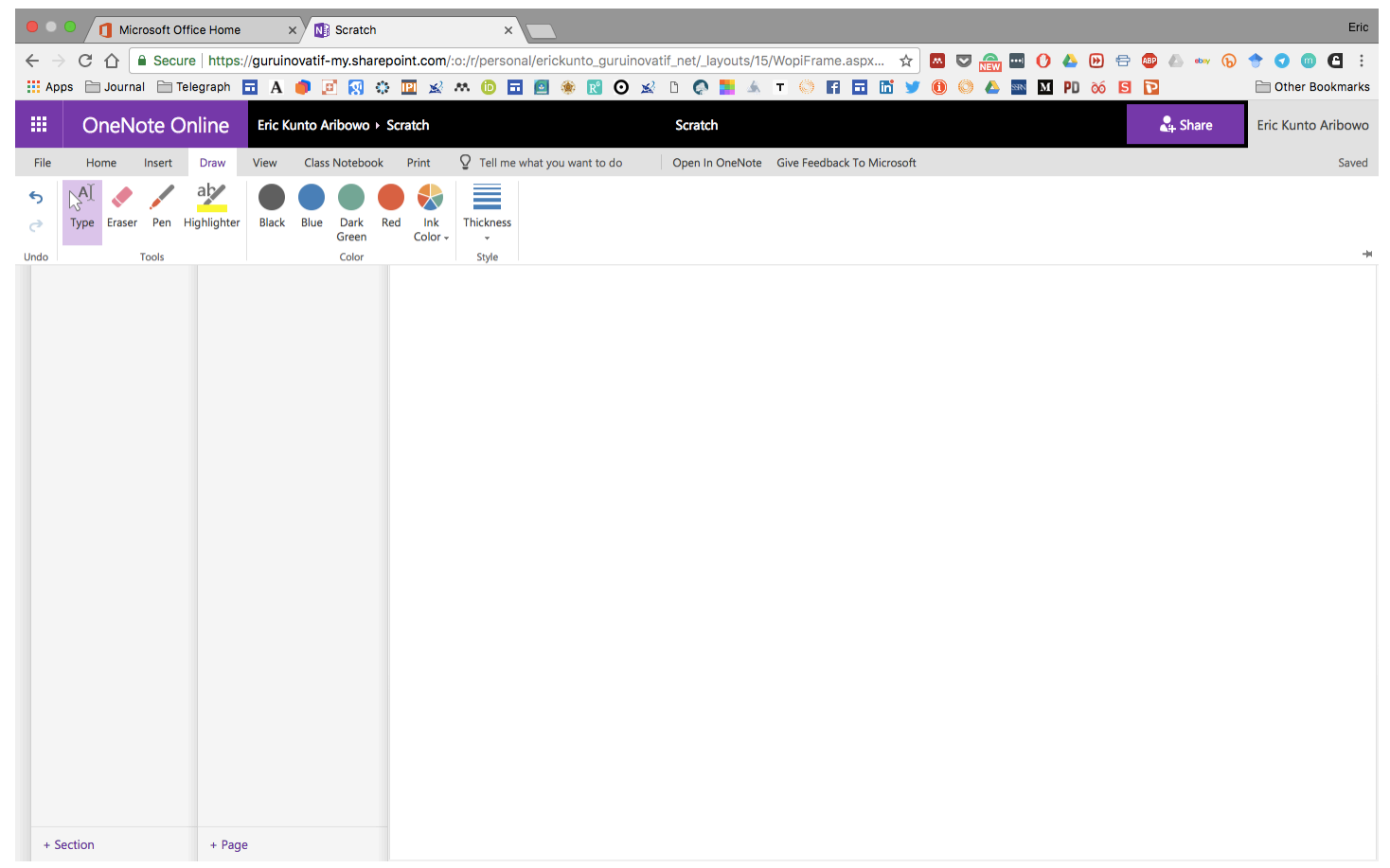

9. Menu "View" untuk mengubah tampilan catatan.

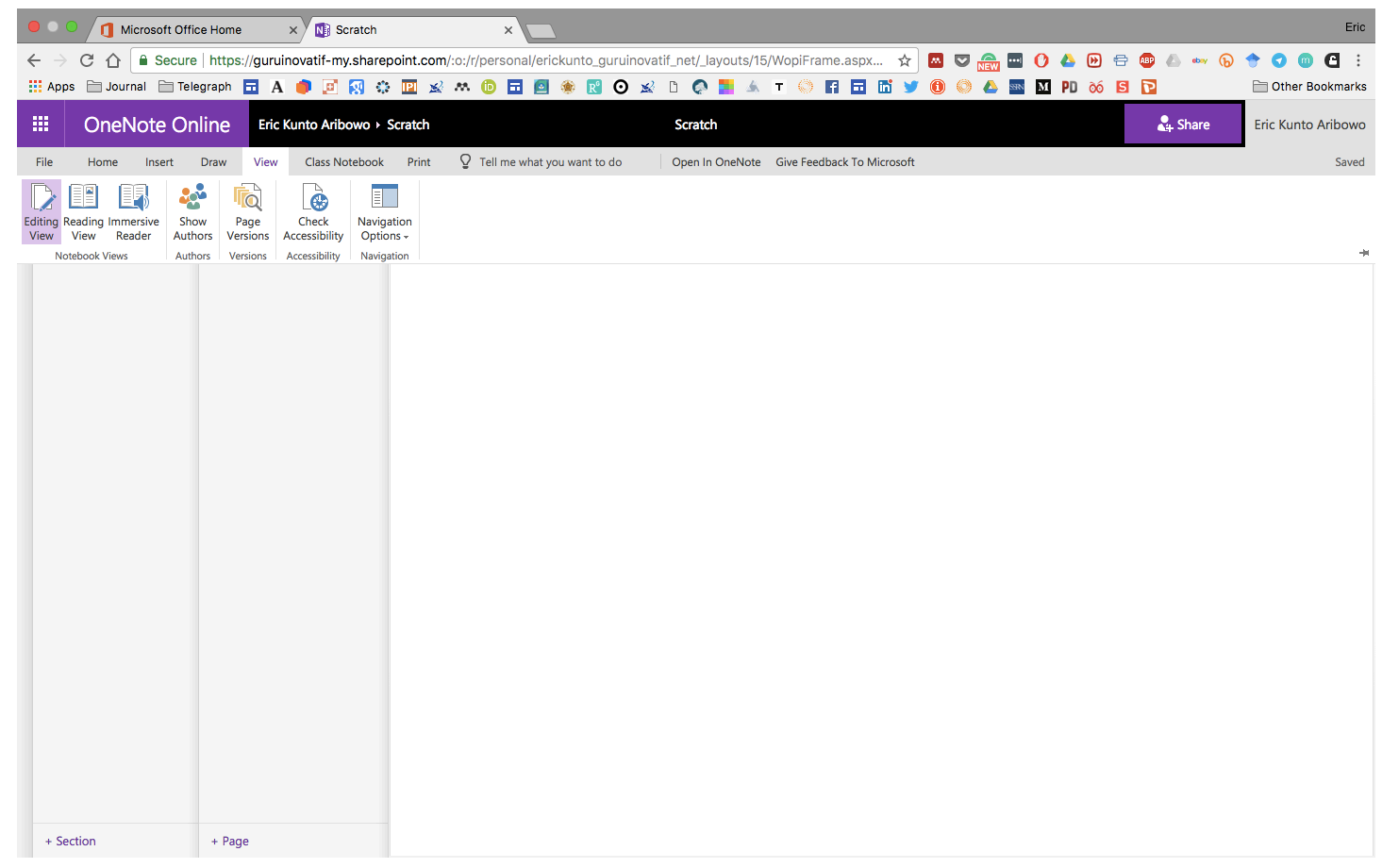


10. Menu "ClassNoteBook" digunakan untuk mengelola buku catatan kelas, misalnya untuk membuat kelas baru, menambah dan mengurangi guru, menambah dan mengurangi siswa, dan lain sebagainya.

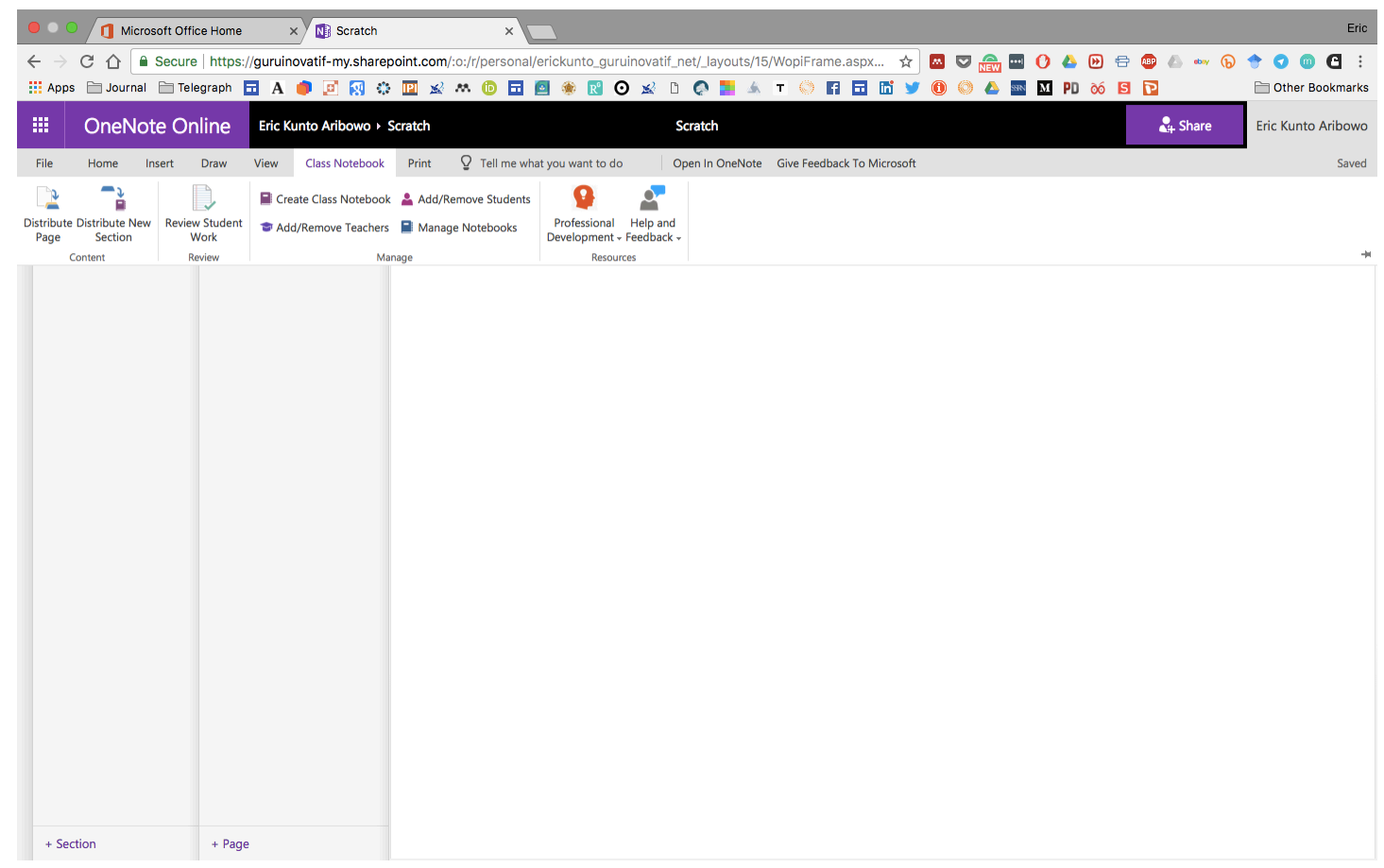

11. Menu "Print" digunakan untuk mencetak hasil catatan yang terdapat pada OneNote.

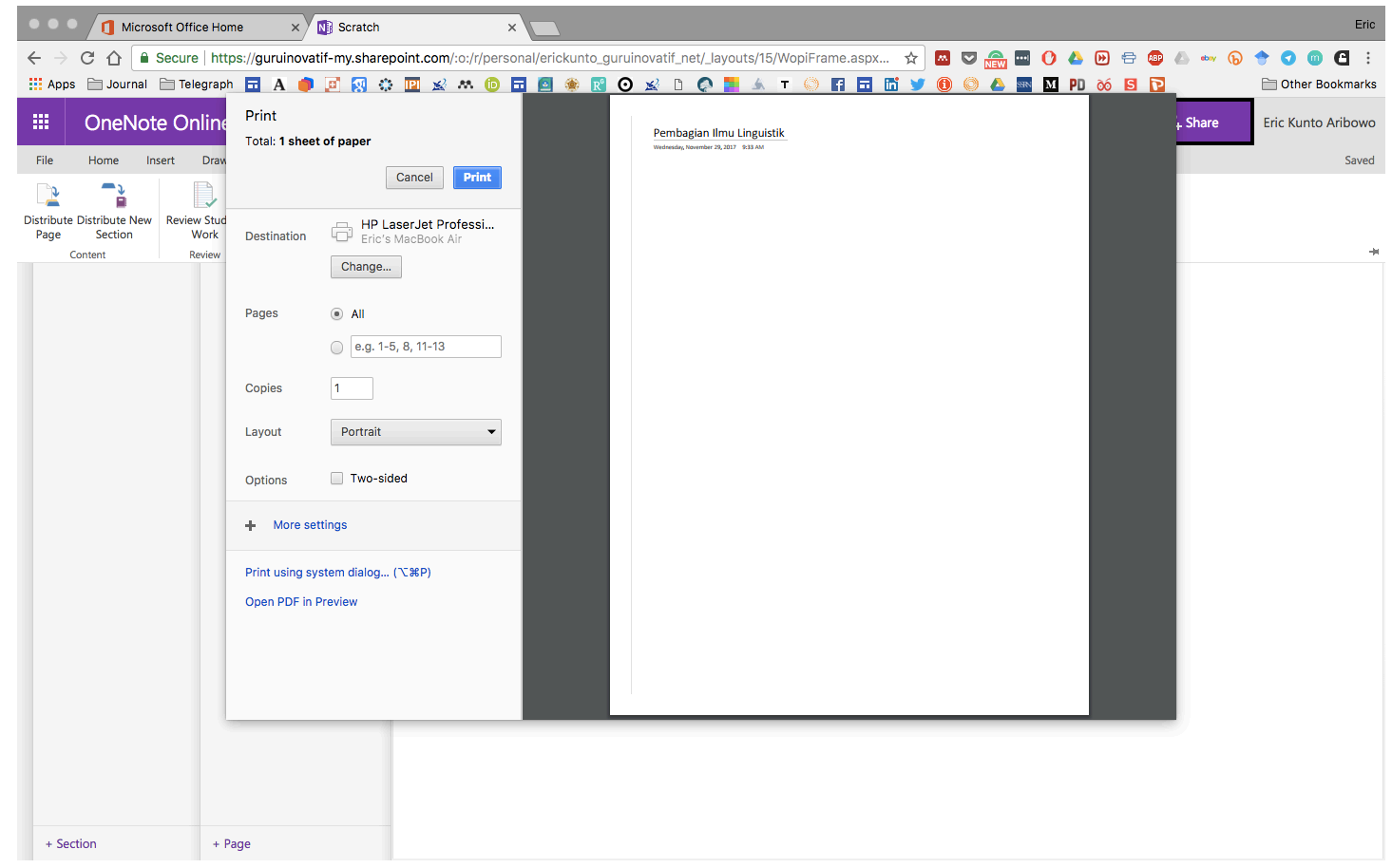


12. Silakan bereksplorasi dengan OneNote. Tambahkan teks atau catatan baru!

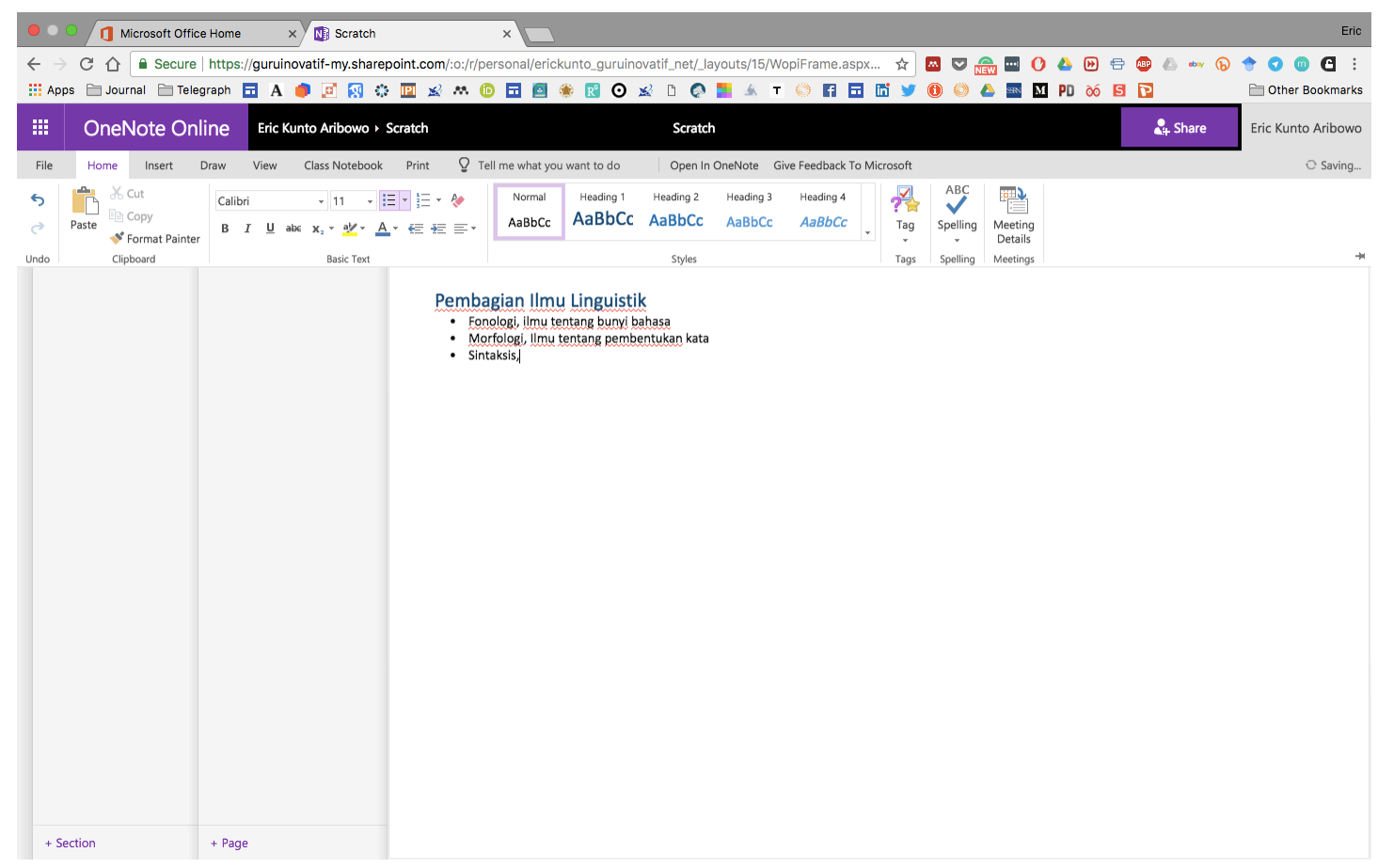

13. Untuk merekam suara ketika perkuliahan atau pembelajaran dapat dilakukan dengan menggunakan menu "Insert" dan pilih opsi "Record Audio".

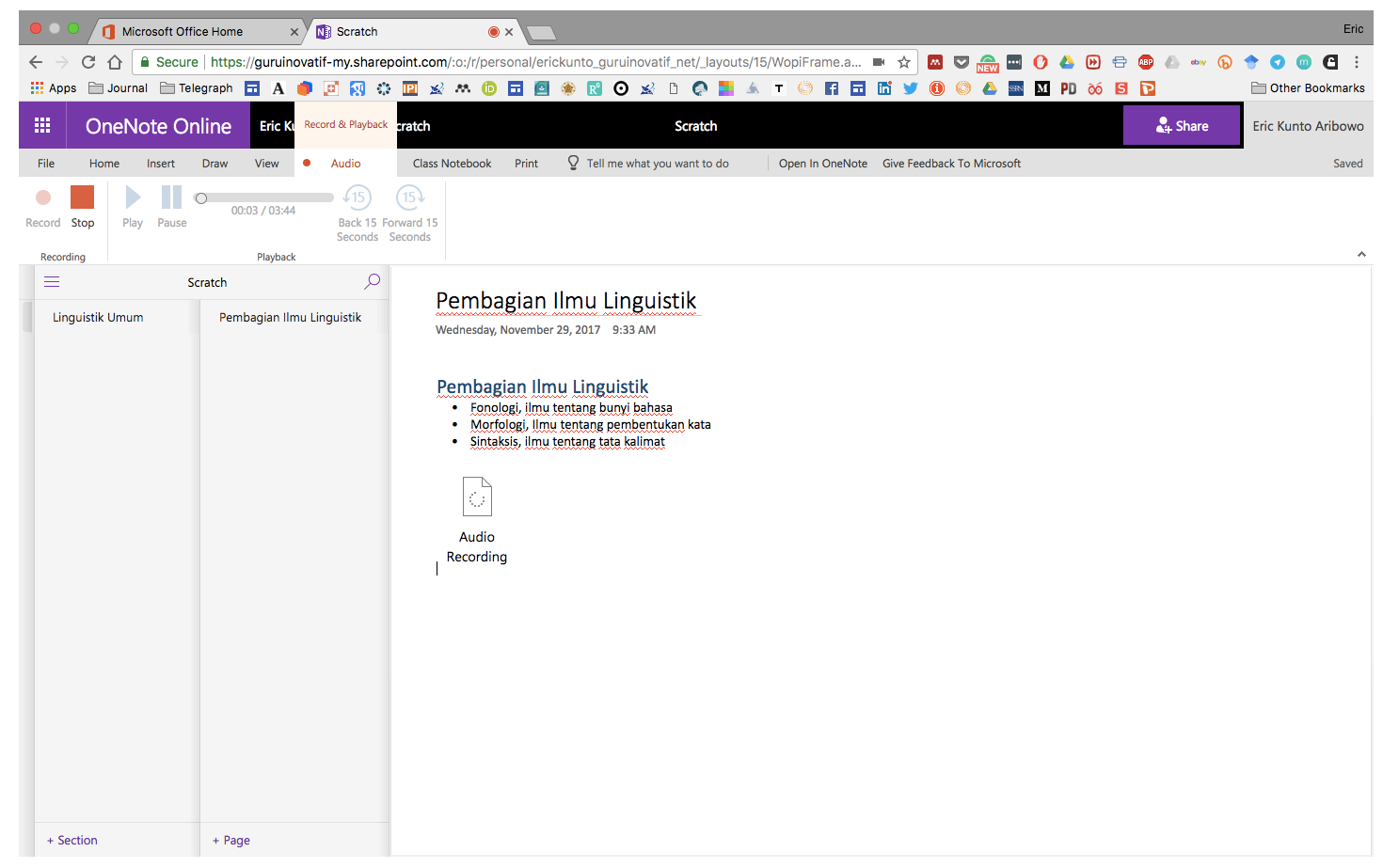


14. Anda juga dapat menyisipkan video dari Youtube atau tautan laman web (sebuah artikel misalnya).

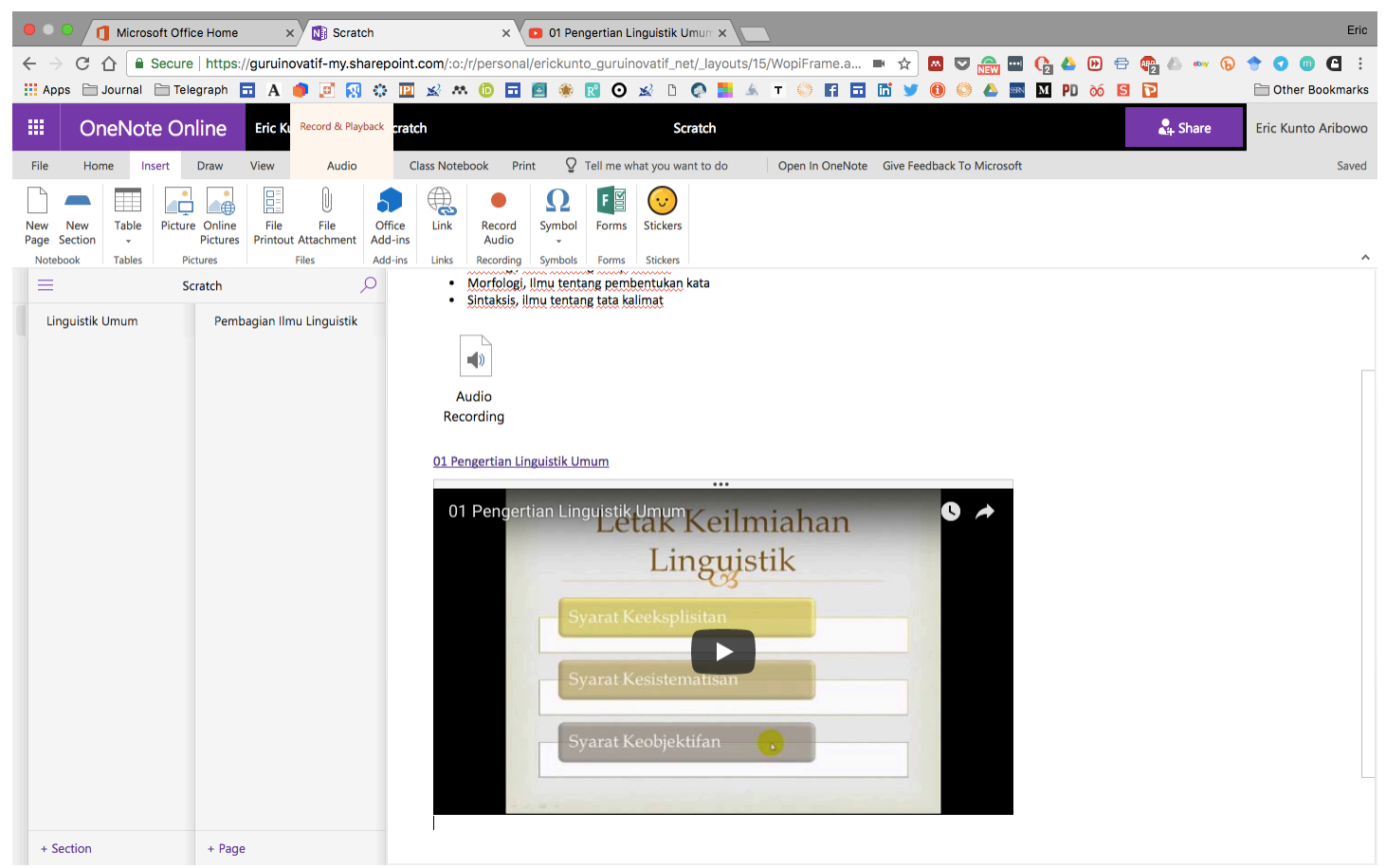

15. Anda juga dapat menyisipkan printout sebuah file, misalnya Silabus, RPP, Kontrak Perkuliahan, Modul, dan lain sebagainya.

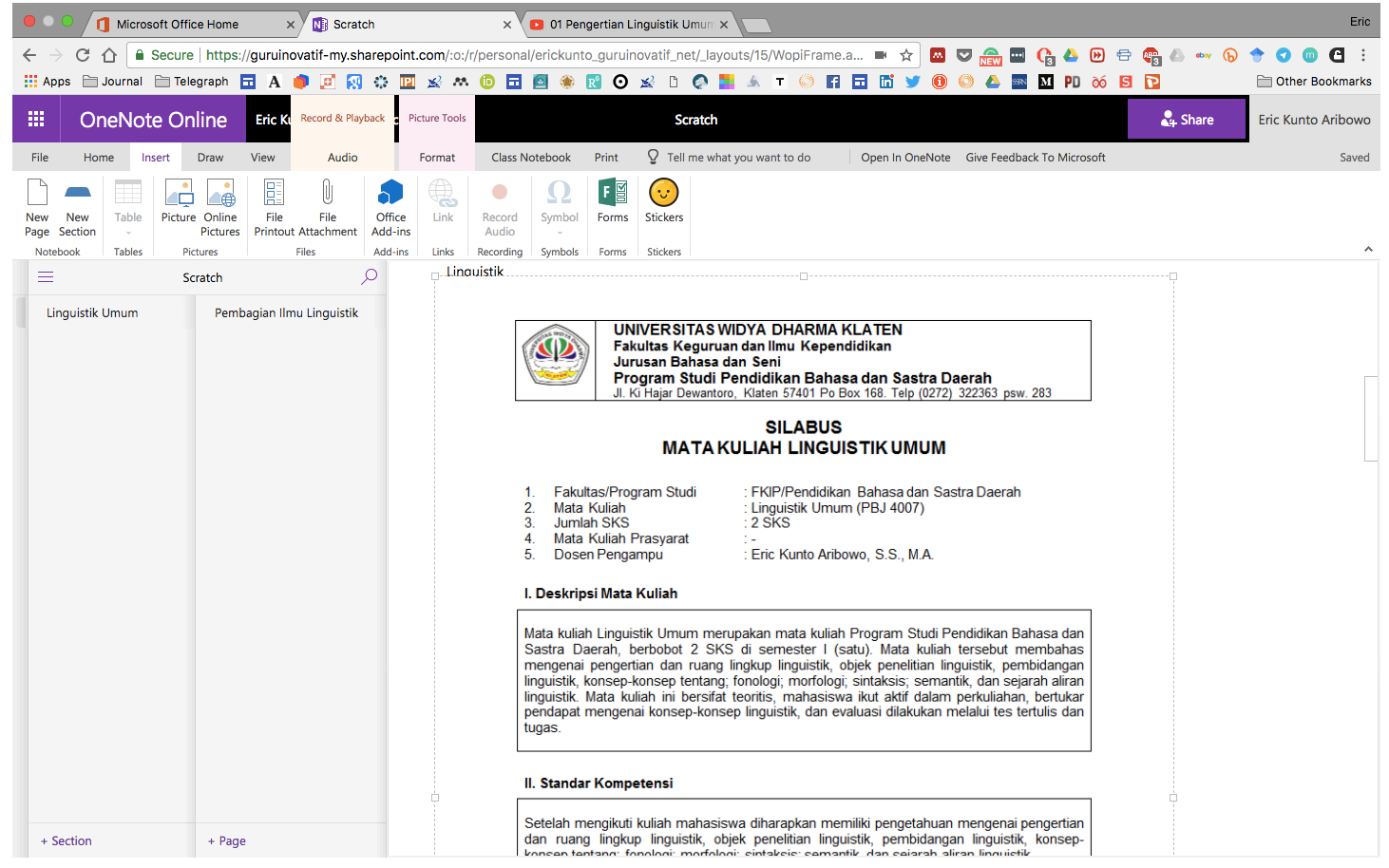


16. Tambahkan stiker untuk memberikan tanda pada catatan-catatan penting Anda.

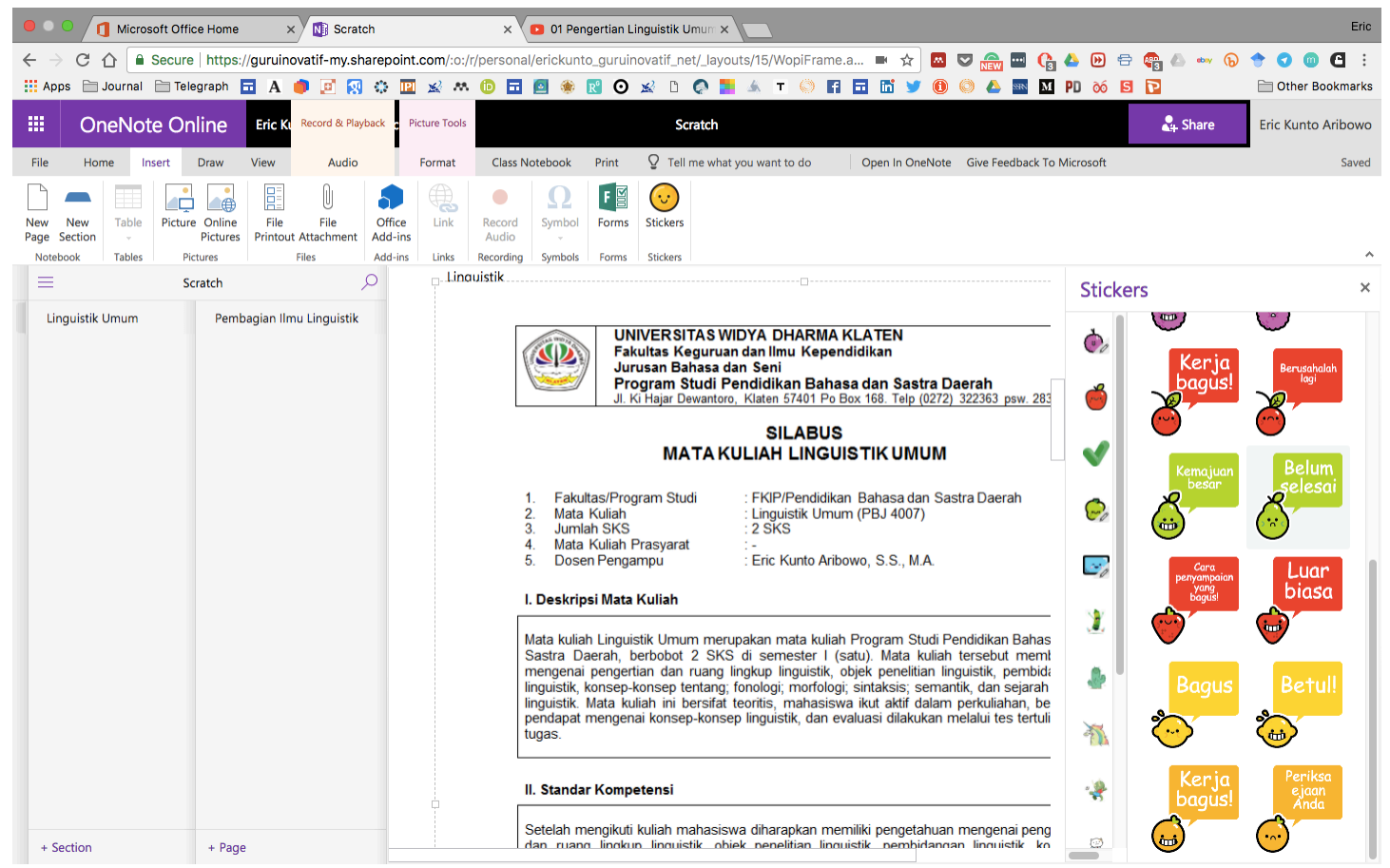

17. Anda juga dapat mengedit stiker dengan menggunakan kata-kata Anda sendiri.

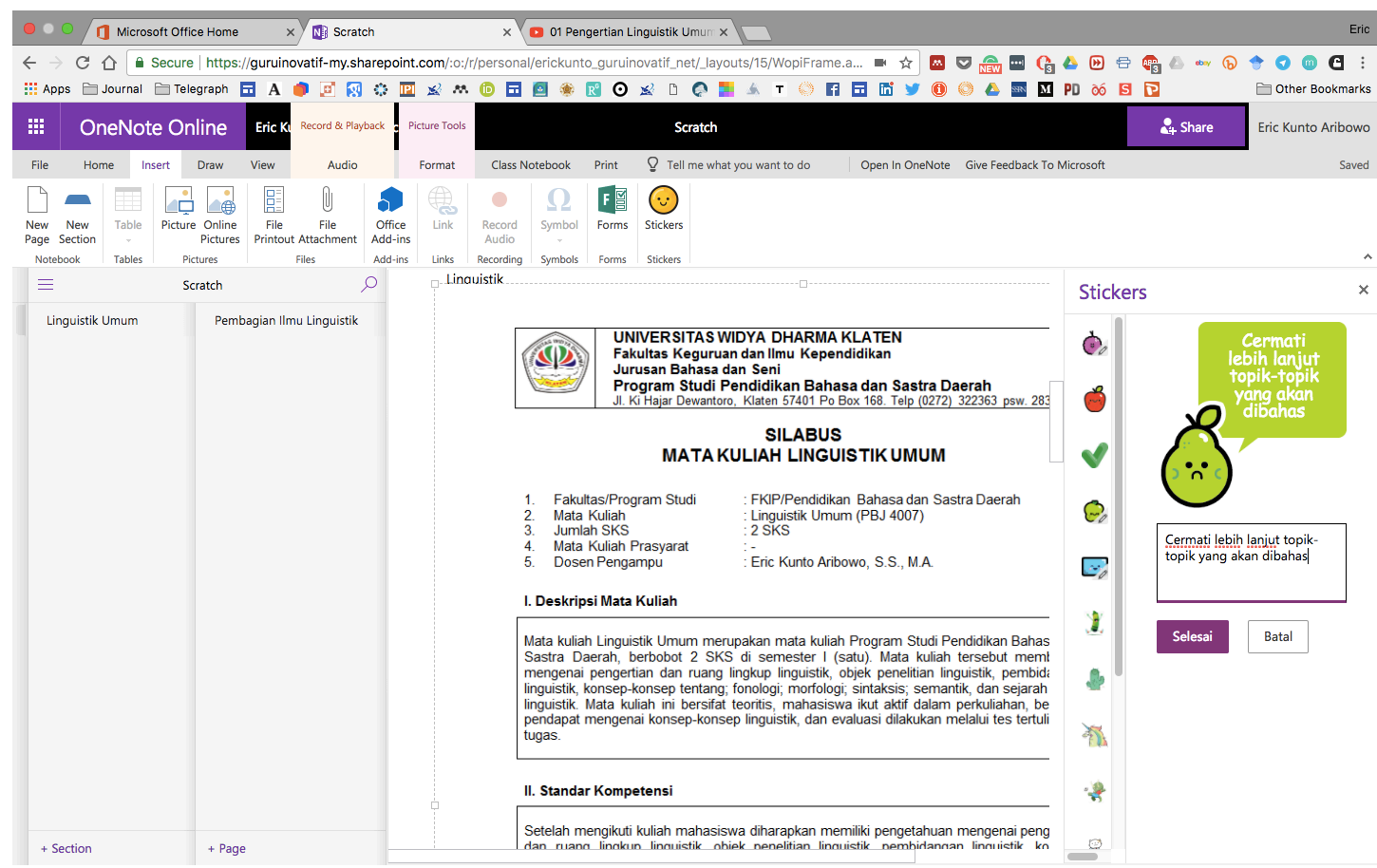

